\title{
Front Matter: Volume 10871
}

, "Front Matter: Volume 10871," Proc. SPIE 10871, Multimodal Biomedical Imaging XIV, 1087101 (12 April 2019); doi: 10.1117/12.2531749

SPIE. Event: SPIE BiOS, 2019, San Francisco, California, United States 


\section{PROGRESS IN BIOMEDICAL OPTICS AND IMAGING}

\section{Multimodal Biomedical Imaging XIV}

Fred S. Azar

Xavier Intes

Qianqian Fang

Editors

2-3 February 2019

San Francisco, California, United States

Sponsored and Published by

SPIE 
The papers in this volume were part of the technical conference cited on the cover and title page. Papers were selected and subject to review by the editors and conference program committee. Some conference presentations may not be available for publication. Additional papers and presentation recordings may be available online in the SPIE Digital Library at SPIEDigitalLibrary.org.

The papers reflect the work and thoughts of the authors and are published herein as submitted. The publisher is not responsible for the validity of the information or for any outcomes resulting from reliance thereon.

Please use the following format to cite material from these proceedings:

Author(s), "Title of Paper," in Multimodal Biomedical Imaging XIV, edited by Fred S. Azar, Xavier Intes, Qianqian Fang, Proceedings of SPIE Vol. 10871 (SPIE, Bellingham, WA, 2019) Seven-digit Article CID Number.

ISSN: 1605-7422

ISSN: 2410-9045 (electronic)

ISBN: 9781510623842

ISBN: 9781510623859 (electronic)

Published by

SPIE

P.O. Box 10, Bellingham, Washington 98227-0010 USA

Telephone +1 3606763290 (Pacific Time) · Fax +1 3606471445

SPIE.org

Copyright (C) 2019, Society of Photo-Optical Instrumentation Engineers.

Copying of material in this book for internal or personal use, or for the internal or personal use of specific clients, beyond the fair use provisions granted by the U.S. Copyright Law is authorized by SPIE subject to payment of copying fees. The Transactional Reporting Service base fee for this volume is $\$ 18.00$ per article (or portion thereof), which should be paid directly to the Copyright Clearance Center (CCC), 222 Rosewood Drive, Danvers, MA 01923. Payment may also be made electronically through CCC Online at copyright.com. Other copying for republication, resale, advertising or promotion, or any form of systematic or multiple reproduction of any material in this book is prohibited except with permission in writing from the publisher. The CCC fee code is 1605$7422 / 19 / \$ 18.00$.

Printed in the United States of America by Curran Associates, Inc., under license from SPIE.

Publication of record for individual papers is online in the SPIE Digital Library.

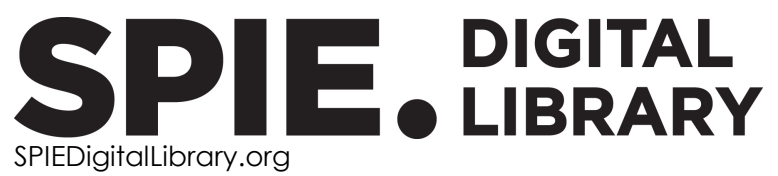

Paper Numbering: Proceedings of SPIE follow an e-First publication model. A unique citation identifier (CID) number is assigned to each article at the time of publication. Utilization of CIDs allows articles to be fully citable as soon as they are published online, and connects the same identifier to all online and print versions of the publication. SPIE uses a seven-digit CID article numbering system structured as follows:

- The first five digits correspond to the SPIE volume number.

- The last two digits indicate publication order within the volume using a Base 36 numbering system employing both numerals and letters. These two-number sets start with 00, 01, 02, 03, 04, 05, 06, 07, 08, 09, OA, OB ... 0Z, followed by 10-1Z, 20-2Z, etc. The CID Number appears on each page of the manuscript. 


\title{
Contents
}

\author{
$\checkmark \quad$ Authors \\ vii Conference Committee
}

MULTIMODAL MICROSCOPY

$1087104 \quad$ Integrated photoacoustic microscopy and optical coherence tomography image-guided laser induced branch retinal vein occlusion in living rabbits [10871-3]

1087107 Sensitivity analysis of a multibranched light guide for real time hyperspectral imaging system [10871-6]

SURGICAL GUIDANCE

$1087108 \quad$ Guidance of percutaneous coronary interventions with NIRS-IVUS for improvement of procedural outcomes and prediction of future risk of coronary events (Invited Paper) [10871-7]

1087109 Discrimination between primary low and high grade tumor and secondary metastasis tumor from deep-UV to NIR [10871-8]

DIFFUSE OPTICS

10871 OF High-resolution chromophore concentration recovery using multi-wavelength photo-magnetic imaging [10871-14]

$108710 G$ Focused $x$-ray luminescence computed tomography: experimental studies [10871-15]

\section{POSTER SESSION}

1087100 Bio-sensor based on multiclass support vector machine with a reject option [10871-23]

10871 OR PET/CT guided time-domain diffuse optical tomography for breast cancer imaging [10871-26]

10871 OU Decentralized autonomous imaging data processing using blockchain [10871-29] 
$10871 \mathrm{OW}$ Characterization of collagen formation surrounding osteocytes using second and third harmonic generation [10871-32]

10871 OY An adaptive-coherence light source for hyperspectral, topographic, and flow-contrast imaging [10871-34]

108710 Combined speckle variance optical coherence tomography and multiphoton microscopy for in vivo chick CAM imaging [10871-36]

108714 Robust sparse reconstruction for Cherenkov luminescence tomography based on look ahead orthogonal matching pursuit algorithm [10871-40]

1087115 Pre-clinical validation of transrectal diffuse optical tomography for monitoring photocoagulation progression during photothermal therapy of prostate cancer [10871-41]

10871 1A Performance improvement of Cerenkov luminescence endoscope by optimizing system structure [10871-46]

10871 1B Reconstruction of membrane shape of a heart assist pump based on spatial interpolation [10871-47]

10871 1C Robust reconstruction of fluorescence molecular tomography based on a two-stage matching pursuit method for in vivo orthotopic hepatocellular carcinoma xenograft mouse model [10871-48]

10871 ID Denoising of low dose CT images using mask non-harmonic analysis with edge-preservation segmentation and whitening filter [10871-49] 


\section{Authors}

Numbers in the index correspond to the last two digits of the seven-digit citation identifier (CID) article numbering system used in Proceedings of SPIE. The first five digits reflect the volume number. Base 36 numbering is employed for the last two digits and indicates the order of articles within the volume. Numbers start with 00, 01, 02, 03, 04, 05, 06, 07, 08, 09, OA, OB...0Z, followed by 10-1Z, 20-2Z, etc.

Aaberg, Micheal, 04

Abi Haidar, D., 09

Algarawi, Maha, OF

Arshad, Arslan, 07

Barrow, Ruth P., OW

Bobrow, Taylor L., OY

Browning, Craig M., 07

Buchsbaum, Stav, 00

Cai, Meishan, 14

Cao, Honghao, IA

$\mathrm{CaO}, \mathrm{Xu}, \mathrm{IA}$

Chalumeau, A., 09

Chen, Duofang, 1A

Chen, Genshe, OU

Chen, Ruibo, 1 A

Chen, Sherry, OU

Chen, Xueli, IA

Chen, YU, OU

Deal, Joshua, 07

Devaux, B., 09

Durr, Nicholas J., OY

Erkol, Hakan, OF

Fisher, Carl J., 15

Gao, Feng, OR

Grainger, Stephanie, 08

Greiner, Cherry, 08

Gulsen, Gultekin, OF

Gunn Mayes, Samantha, 07

$\mathrm{Ha}$, Seunghoon, OF

Hasegawa, Masaya, 1D

He, Jie, 15

Henry, Jessica, 04

Hirobayashi, Shigeki, ID

Hu, Zhenhua, 14

Jamme, F., 09

Keshet, Yossi, 00

Leavesley, Silas J., 07

Li, Celina L., 15

Li, Changqing, OG, OR

Li, Yanxiu, 04

Liang, Jimin, $1 \mathrm{~A}$

Liang, Shuhui, IA

Lu, Xiaojian, IA

Luk, Alex, OF

Lun, Michael C., OG

Ma, Yiwen, OR

Madden, Sean, 08

Mayes, Samuel, 07

Mehidine, H., 09
Mehrabi, Mehrnaz, OF

Mortensen, Luke J., OW

Murawski, Krzysztof, 1B

Nguyen, Van Phuc, 04

Nouizi, Farouk, OF

Ozana, Nisan, 00

Parker, Marina, 07

Paulus, Yannis M., 04

Pendleton, Emily G., OW

Poulon, F., 09

Refregiers, M., 09

Rich, Thomas C., 07

Rosen, Rachel, 04

Shah, Priti, 08

Shi, Runjie Bill, 15

Sulej, Wojciech, 1B

Tang, Shuo, 10

Tehrani, Kayvan F., OW

Tian, Jie, 14, 1C

Uchikoshi, Kousei, ID

Ünlü, Mehmet Burçin, OF

Varlet, P., 09

Wang, Kun, 1C

Wang, Xueding, 04

Weersink, Robert A., 15

Wilson, Brian C., 15

Wu, Kaichun, IA

$\mathrm{XU}$, Ronghua, OU

Yang, Lixin, $O U$

Yin, Lin, 1C

Zalevsky, Zeev, 00

Zhan, Yonghua, IA

Zhang, Wei, 04, OG

Zhang, Zeyu, 14

Zheng, Gang, 15

Zhou, Yonghan, 10 
Proc. of SPIE Vol. 10871 1087101-6

Downloaded From: https://www.spiedigitallibrary.org/conference-proceedings-of-spie on 26 Apr 2023 Terms of Use: https://www.spiedigitallibrary.org/terms-of-use 


\section{Conference Committee}

Symposium Chairs

James G. Fujimoto, Massachusetts Institute of Technology (United States)

R. Rox Anderson, Wellman Center for Photomedicine, Massachusetts General Hospital (United States) and Harvard Medical School (United States)

Symposium Co-chairs

Jennifer K. Barton, The University of Arizona (United States)

Wolfgang Drexler, Medical University of Vienna (Austria)

Program Track Chairs

Tuan Vo-Dinh, Fitzpatrick Institute for Photonics, Duke University (United States)

Anita Mahadevan-Jansen, Vanderbilt University (United States)

Conference Chairs

Fred S. Azar, IBM Watson Health United States)

Xavier Intes, Rensselaer Polytechnic Institute (United States)

Qianqian Fang, Northeastern University (United States)

Conference Program Committee

Caroline Boudoux, Ecole Polytechnique de Montréal (Canada) Christophe Chefd'hotel, Ventana Medical Systems, Inc. (United States)

Yu Chen, University of Maryland, College Park (United States)

Qianqian Fang, Massachusetts General Hospital (United States)

Gultekin Gulsen, University of California, Irvine (United States)

Changqing Li, University of California, Merced (United States)

Brian W. Pogue, Thayer School of Engineering at Dartmouth (United States)

Arjun G. Yodh, University of Pennsylvania (United States)

Session Chairs

1 Multimodal Microscopy

Fred S. Azar, IBM Watson Health (United States)

Qianqian Fang, Northeastern University (United States) 
2 Surgical Guidance

Qianqian Fang, Northeastern University (United States)

Fred S. Azar, IBM Watson Health (United States)

3 Diffuse Optics

Qianqian Fang, Northeastern University (United States)

Changqing Li, University of California, Merced (United States)

4 Deep Learning

Fred S. Azar, IBM Watson Health (United States)

Xavier Intes, Rensselaer Polytechnic Institute (United States) 